\title{
Immunogenicity Specimen Assessments Test Code
}

National Cancer Institute

\section{Source}

National Cancer Institute. Immunogenicity Specimen Assessments Test Code. NCI

Thesaurus. Code C117555.

A character or string that represents the short code name of the immunogenicity specimen assessment. 